\title{
ANALISIS PENGGUNAAN BAHAN PENGEMAS PADA MANISAN KERING TERONG HIJAU (Solanum melongena L)
}

\section{ANALYSIS THE USE OF PACKAGING MATERIALS IN SWEET DRYING GREEN EGGPLANT (Solanum melangena L)}

\author{
Rosiana Ulfa $^{1)}$, Restiani Sih Harsanti ${ }^{2)}$, Mohammad Rifkhi Azis ${ }^{3)}$ \\ 1),2),3)Universitas PGRI Banyuwangi \\ Email: roshi_n2002@yahoo.com
}

diterima : 14 Januari 2019; dipublikasi: 30 Maret 2019

DOI: http://dx.doi.org/10.32528/bioma.v4i1.2650

\begin{abstract}
ABSTRAK
Perkembangan produk olahan pangan bersifat dinamis, berbagai cara dilakukan untuk dapat memperpanjang umur simpan dan mengurangi kerusakan produk pangan, salah satu adalah dengan melakukan pengemasan. Produk manisan terong merupakan salah satu upaya olahan alternatif dari terung hijau, untuk meningkatkan jumlah konsumsi dan pemanfaatannya. Penelitian ini bertujuan untuk mengetahui bahan pengemas plastik yang tepat untuk memperpanjang umur simpan dari manisan terung hijau. Hasil penelitian didapatkan setelah melakukan pembuatan manisan kering terung hijau yang diawali dengan tahap pencucian, penusukan, perendaman, pemasakan, pengeringan, pengemasan dan penyimpanan selama 7 hari. Kadar air manisan terung terbaik diketahui pada kemasan jenis plastik PE yaitu sebesar 33,8\%. Sedangkan nilai ALT menunjukkan bahwa semakin rendah permeabilitas kadar air yang dimiliki oleh jenis bahan pengemas, maka semakin besar kemungkinan bagi mikroorganisme untuk tumbuh. Bahan pengemas jenis LDPE memiliki nilai ALT yang paling tinggi diantara PE, PET dan kombinasi LDPE. Hal ini diarenakan permeabilitasnya terhadap udara cukup tinggi.
\end{abstract}

Kata Kunci: Pengemasan, Manisan Kering, Solanum melonga $L$

\section{ABSTRACT}

The development of processed food products is dynamic, various methods are used to extend shelf life and reduce damage to food products, which is by packaging. Candied eggplant products are one of the alternative processed efforts of green eggplant, to increase the amount of consumption and utilization. This study aims to determine the right plastic packaging material to extend the shelflife of candied green eggplants. The result were obtained after making dried green eggplant candied which begins with the stage of washing, stabbing, soaking, cooking, drying, packaging and storage for 7 days. The best level of eggplants preserved water are known on the packaging type of plastic mika that is equal to $33,8 \%$. While the ALT indicates that the lower the permeability of the water content by the type of packaging material, the more likely it is for microorganisms to grow. LDPE material packaging have the highest ALT value among PE, PET dan LDPE combinations packaging. This is because the permeability to oxygen is quite high.

Keywords: Packaging, Sweet drying, Solanum melonga $L$ 


\section{PENDAHULUAN}

Produk pangan merupakan jenis produk yang sangat mudah sekali mengalami kerusakan, karena itu diperlukan pengemas untuk dapat memperpanjang umur simpannya. Tujuan awal penggunaan pengemas adalah untuk mengurangi kerusakan pada bahan pangan, namun pada perkembangannya pengemasan juga memberikan nilai estetika dan nilai ekonomis yang lebih tinggi terhadap produk yang dikemasnya.

Produk manisan, merupakan salah satu produk pangan yang digemari mulai anakanak hingga dewasa. Rasanya yang manis serta cara pembuatannya yang mudah membuat manisan kering terung hijau ini memiliki prospek yang bagus untuk dipasarkan. Standar manisan buah kering yang digunakan harus mengikuti standar mutu manisan buah kering oleh Badan Standar Nasional Indonesia (SNI), kadar air maksimal dari manisan buah kering adalah tidak boleh lebih dari $25 \%$, dan pada pemeriksaan biologi dinyatakan tidak pada bakteri golongan E.coli dll tidak ada, seperti ditunjukkan pada Tabel 1.

Tabel 1. Standar Nasional Indonesia Manisan Buah Kering (SNI 01-4443-1998).

\begin{tabular}{|c|c|c|}
\hline No & Parameter & Satuan \\
\hline 1 & Keadaan (kenampakan, bau, rasa dan jamur) & Normal tidak berjamur \\
\hline 2 & Kadar air & Maks $25 \%(\mathrm{~b} / \mathrm{b})$ \\
\hline 3 & Jumlah gula (dihitung sebagai sukrosa) & Min $40 \%$ \\
\hline 4 & Pemanis buatan & Tidak ada \\
\hline 5 & Zat warna & $\begin{array}{l}\text { Yang diizinkan } \\
\text { makanan }\end{array}$ \\
\hline 6 & $\begin{array}{l}\text { Benda asing (daun, tangkai, pasir dan lain- } \\
\text { lain) }\end{array}$ & Tidak ada \\
\hline 7 & Bahan pengawet (dihitung sebagai $\mathrm{SO}_{2}$ ) & Maks $50 \mathrm{mg} / \mathrm{kg}$ \\
\hline \multirow[t]{5}{*}{8} & Cemaran logam: & \\
\hline & Tembaga $(\mathrm{Cu})$ & Maks. 50 mg/kg \\
\hline & Timbal $(\mathrm{Pb})$ & Maks. $2,5 \mathrm{mg} / \mathrm{kg}$ \\
\hline & Seng $(\mathrm{Zn})$ & Maks. 40 mg/kg \\
\hline & Timah (Sn) & Maks $150 \mathrm{mg} / \mathrm{kg}^{*}$ \\
\hline 9 & Arsen & Maks 1,0 mg/kg \\
\hline \multirow[t]{3}{*}{10} & Pemeriksaan mikrobiologi & \\
\hline & Golongan bentuk E.coli & Tidak ada \\
\hline & Bakteri Eschericchia coli & Tidak ada \\
\hline
\end{tabular}

Keterangan: $\left.{ }^{*}\right)$ produk yang dikalengkan

Sumber : SNI (1998). 
Produk manisan dapat dibagi menjadi 4 kelompok: (1) Manisan basah adalah manisan yang terbuat dari hasil perendaman buah dengan larutan gula encer jenis buah yang biasa digunakan pada manisan adalah jenis buah berdaging keras yaitu salak dan jambu, (2) Manisan gula kental adalah manisan yang terbuat dari larutan gula $\pm 60 \%$ yang digunakan untuk merendam buah, contohnya adalah manisan cermai (3) Manisan kering adalah manisan yang sebagian gulanya tidak larut dan menempel pada produk misalnya adalah manisan pala, mangga dll (4) manisan kering asin adalah manisan dengan unsur dominan adalah garam, yang sering digunakan pada proses pembuatan manisan kering asin adalah buah jambu monyet (Pratami, 2013).

Salah satu penyebab kerusakan pada produk manisan adalah adanya kontak antara produk dengan udara sehingga memicu tumbuhnya mikroorganisme seperti kapang dan khamir. Badan Pengawas Obat dan Makanan menetapkan, batas maksimum cemaran kapang dalam manisan buah kering adalah 5 x 101 koloni/gram, selain untuk menghindari penurunan kualitas dan umur simpan, batasan ini juga diberikan untuk menghindari adanya zat racun yang dihasilkan oleh kapang jenis tertentu pada makanan.

Terung adalah salah satu jenis sayuran yang kurang termanfaatkan secara luas, selama ini terung hanya digunakan sebagai sayur maupun lalapan. Beberapa jenis terung yang dikonsumsi antara lain: (1) Terung kopek yang memiliki bentuk bulat panjang dengan ujung tumpul berwarna ungu dan hijau keputihan, (2) terung craigi berbentuk bulat panjang dengan ujung runcing, dan buah berwarna ungu atau hijau, (3) terung bogor bentuk buah bulat besar dan berwarna putih dan memiliki ciri khas tekstur renyah dan rasa agak getir, (4) terung gelatik memiliki penampakan seperti terung bogor tetapi lebih kecil dan banyak digunakan sebagai lalapan (Santoso, 2016).

Untuk meningkatkan penggunaan dan daya tarik masyarakat terhadap terung hijau, perlu dilakukan berbagai alternatif bentuk olahan dari buah terung hijau, salah satunya adalah pembuatan produk manisan terung hijau. Produk manisan terung dipilih karena jenis produk ini mudah dibuat dan digemari semua kalangan, hanya saja tingginya kadar gula yang dimiliki menyebabkan produk ini rentan mengalami kerusakan.

Pengemasan merupakan kegiatan menempatkan produk ke dalam wadah yang dilakukan oleh produsen untuk disampaikan kepada konsumen. Dengan meningkatkan teknik pengemasan dan penyimpanan diharapkan dapat meningkatkan umur simpan dan jumlah nutrisi serta energi dari pangan yang higienis dan menarik (Syarief dan Sukri, 2016). 
Berbagai jenis bahan pengemas yang beredar dipasaran. Penggunaan bahan pengemas, harus disesuaikan dengan sifat bahan yang dikemas. Polyethylene (PE) merupakan kemasan plastik yang fleksibel dan umum digunakan untuk mengemas produk ikan dan daging. Sifat dari Polyethylene antara lain: (1) mudah dibentuk dan lemas, (2) tahan terhadap asam basa, (3) kedap air dan uap, (4) daya rentang tinggi tanpa sobek, (5) mudah dikelim panas, (6) permeabilitas agak tinggi (Johansyah et al, 1989).

Polyethylene terephthalate (PET) dibuat dari glikol dan terephthalate acid memiliki sifat jernih, kuat, liat, tahan nyala api, tidak beracun dan permeabilitas gas, aroma maupun air rendah (Mujiarto, 2005). Sedangan untuk jenis platik LDPE memiliki sifat yang hampir sama dengan platik jenis PE yaitu memiliki permeabilitas agak tinggi (Wulandari et al, 2013).

\title{
BAHAN DAN METODE
}

\section{Bahan}

Terung hijau (Solanum melongena L), gula pasir, kayu manis, air kapur sirih, asam sitrat, PDA (Potato Dextrose Agar), plastik mika (PE), plastik PET, stand up pouch (LDPE), plastik stand up pouch (alumunium + LDPE), kertas pembungkus, larutan buffer pepton.

\author{
Alat \\ Loyang alumunium, sealer manual, kabinet dryer, petridish, pipet cawan porselin, desikator, \\ timbangan analitik, bunsen, oven dll
}

\section{Metode}

Penelitian ini dilakukan dengan membuat manisan kering pada konsentrasi yang tepat kemudian dilakukan pengemasan dan penyimpanan terhadap manisan yang sudah jadi dengan menggunakan empat jenis bahan pengemas yang berbeda. Pengemas plastik digunakan untuk mengetahui perubahan fisik yang terjadi pada manisan kering terung hijau. Penyimpanan dilakukan selama 7 hari dan pengukuran diulang sebanyak 3 kali (Nofriati, 2013).

\section{Kadar air}

Analisa kadar air dilakukan dengan metode thermogravimetri menurut Putri et al (2015), dilakukan dengan cara mengambil sejumlah sampel diletakkan pada cawan kosong yang telah ditimbang sebelumnya, kemudian ditimbang dengan menggunakan timbangan analitik untuk diketahui beratnya dan dicatat, kemudian dimasukkan kedalam oven selama 24 
jam dan dikeluarkan dan dimasukkan ke dalam desikator selama 20 menit dan ditimbang kembali. Prinsip dasar dari metode ini adalah menghitung selisih dari berat sebelum dan sesudah sampel dipanaskan. Selisih bobot tersebut merupakan air yang teruapkan dan dihitung sebagai kadar air bahan, dengan perhitungan sebagai berikut:

kadar air $(\%)=\frac{\text { berat awal }- \text { berat akhir }}{\text { berat sampel }} \times 100 \%$

\section{Penghitungan Angka Total Lempeng Mikroba}

Dilakukan dengan mengambil sampel sebanyak 15 gram sampel, dimasukkan ke dalam botol pengencer yang telah berisi $125 \mathrm{ml}$ larutan buffer pepton dan diaduk hingga homogen dan dilakukan pengenceran $10^{-5}$ (Atma, 2016). Setelah itu setiap seri pengenceran di inkubasi pada media agar selama 7 hari kemudian diamati jumlah koloni yang tumbuh pada setiap petridish.

\section{HASIL DAN PEMBAHASAN}

Pengolahan terung hijau menjadi produk manisan kering terung, merupakan salah satu cara meningkatkan nilai jual dari terung. Salah satu alasan dipilihnya jenis terung hijau adalah tingkat produktivitas terung jenis ini cukup tinggi dan mudah dibudidayakan.

Proses pembuatan manisan kering terung hijau diawali dengan mencuci dan merendam sampel buah terung kedalam larutan kapur selama 10 jam dengan tujuan untuk memberikan tekstur bagi manisan kering terung hijau. Setelah itu terung direndam dan dipanaskan pada larutan gula dengan perbandingan antara gula dan air 1:1 hingga permukaan terung terlihat mengkilat dan larutan gula menyusut hingga separuh. Manisan terung yang masih basah, kemudian dikeringkan dalam cabinet dryer selama 8 jam atau hingga mencapai kadar air kurang dari $25 \%$.

Pengemasan dilakukan dengan memasukkan manisan terung ke dalam setiap jenis bahan pengemas yang kemudian direkatkan dengan menggunakan sealer manual. Selain itu juga disiapkan sampel yang tidak dikemas sebagai kontrol atau pembanding.

Tingginya kadar gula yang dimiliki oleh manisan terung membuat produk pangan jenis ini rentan mengalami kerusakan akibat kapang apabila disimpan terlalu lama pada suhu 
kamar. Pemilihan jenis kemasan yang tepat diharapkan dapat mengurangi kerusakan produk selama penyimpanan.

\section{Analisa Kadar Air}

Kandungan air pada bahan hasil pertanian memiliki pengaruh besar terhadap kerusakan bahan pangan, semakin tinggi kadar air pada bahan pangan, semakin pendek umur simpan dari produk pangan tersebut. Berdasarkan Standar Nasional Indonesia, kadar air manisan buah kering adalah kurang dari $40 \%$, hal inilah yang menjadi pedoman dalam pembuatan manisan kering yang telah dilakukan. Sebelum di lakukan pengemasan, manisan kering terung hijau memiliki kadar air sebesar 25,73. Setelah itu dilakukan penyimpanan selama 7 hari kemudian dilakukan kembali uji kadar air untuk mengetahui pengaruh setiap jenis kemasan. Untuk hasil uji kadar air manisan kering terung hijau (Solanum melongena L) setelah melalui proses penyimpanan digambarkan dalam gambar dibawah ini.

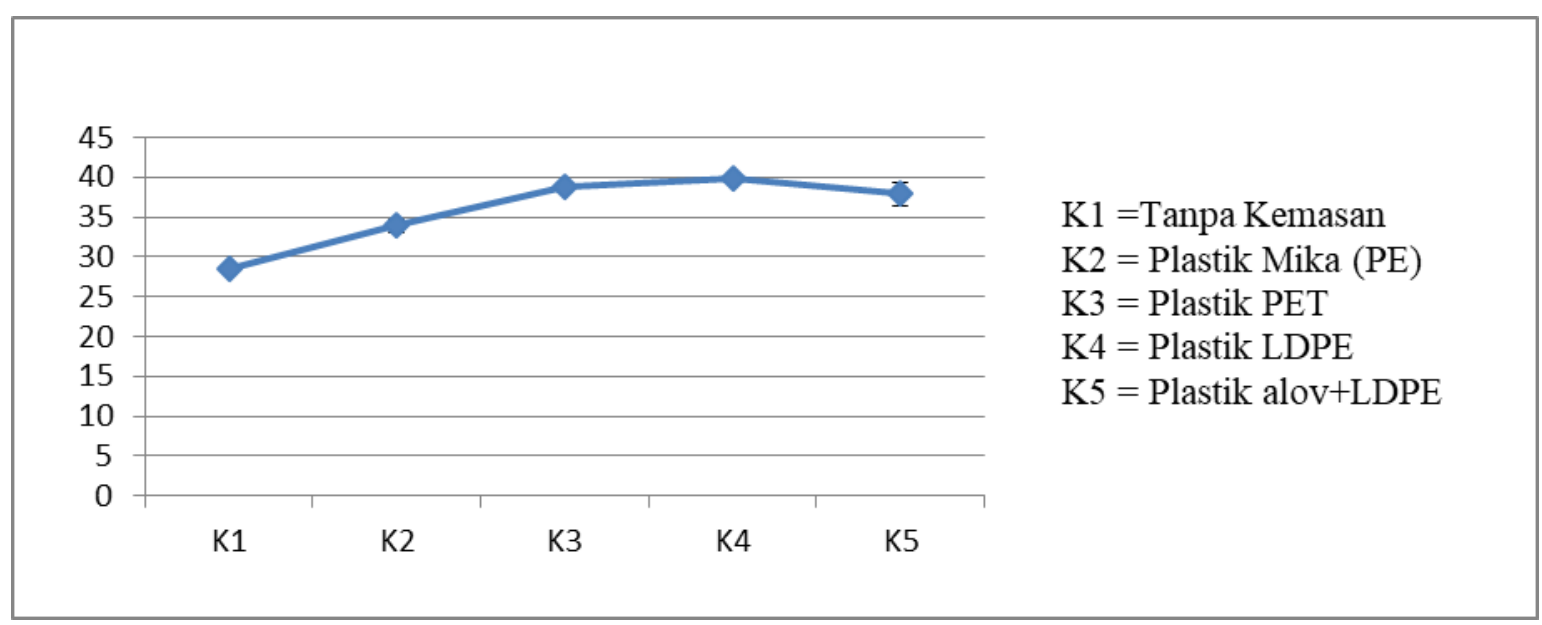

Gambar 1. Kadar Air Manisan Kering Pada Berbagai Jenis Bahan Pengemas Plastik.

Berdasarkan hasil penelitian diketahui bahwa pengemasan selama 7 hari menyebabkan kadar air manisan terung kering meningkat. Rata-rata manisan kering terung hijau setelah penyimpanan memiliki kadar air diatas 35\%. Apabila dibandingkan dengan standar manisan kering pala, kadar air manisan terung hijau kering tidak sesuai dengan kadar air manisan kering (melebihi batas maksimal dari SNI).

Manisan terung kering yang dikemas menggunakan mika yang terbuat dari plastik jenis PE menunjukkan kadar air paling rendah diantara jenis pengemas lainnya. Plastik jenis PE 
memiliki permeabilitas udara yang agak tinggi, namun permeabilitas uap air dan air rendah, sehingga meskipun tingginya gula yang memiliki sifat higroskopis dapat menyebabkan peningkatan kadar air selama penyimpanan, namun peningkatan kadar air tidak terjadi terlalu cepat.

Kemasan jenis LDPE (Low Density Polyethylene) sangat susah dihancurkan tetapi sangat cocok digunakan sebagai bahan pengemas makanan. Plastik jenis ini sangat kuat, agak tembus cahaya dan fleksibel, namun permeabilitas terhadap gas sejenis oksigen sangat tinggi. Kadar air manisan kering terung hijau yang dikemas dengan plastik LDPE memiliki kadar air paling tinggi yaitu 39,91\%. Tingginya kadar air pada manisan terong, selain dikarenakan sifat plastik LDPE yang tidak resisten terhadap gas-gas sejenis oksigen, juga dikarenakan sifat gula yang higroskopis.

Kemasan yang menggunakan jenis plastik PET memiliki permeabilitas udara yang rendah, dan permeabilitas uap air serta air cukup tinggi, hal ini menyebabkan kadar uap air yang berada dalam kemasan meningkat lebih cepat. Peningkatan kadar air pada kemasan dengan menggunakan plastik jenis ini semakin cepat diakibatkan sifat gula yang higroskopis.

Berbeda dengan kadar air manisan terong yang tidak dikemas, pada sampel yang tidak dikemas kadar air cukup rendah, hal ini dikarenakan pada manisan terong yang dikemas tidak terjadi peningkatan kadar air selama masa penyimpanan. Hal ini menunjukkan bahwa jenis makanan yang memiliki kadar gula tinggi membutuhkan jenis pengemas yang memiliki permeabilitas udara tinggi namun kedap uap air.

\section{Perhitungan Angka Lempeng Mikroba}

Salah satu faktor penyebab kerusakan makanan adalah keberadaan mikroorganisme tertentu pada bahan pangan. Beberapa diantaranya yaitu bakteri, kapang dan khamir yang mampu tumbuh pada kondisi aerob maupun anaerob. Pada produk manisan kering yang memiliki kadar gula tinggi dan kadar air yang rendah, jenis mikroorganisme yang mungkin tumbuh antara lain adalah kapang dan khamir.

Pengemas jenis LDPE memiliki permeabilitas udara tinggi dan tingginya kadar gula pada bahan pangan juga menyebabkan kandungan air didalam kemasan meningkat, hal ini dikarenakan sifat gula yang higroskopis atau mudah menyerap air sehingga peluang mikroorganisme untuk tumbuh semakin besar, terutama mikroorganisme jenis khamir. 
Aktivitas air menunjukkan jumlah air yang terdapat pada bahan pangan yang dapat digunakan oleh mikroorganisme untuk berkembang biak, semakin tinggi aktivitas air yang dimiliki oleh bahan pangan, maka semakin besar kemungkinan bahan pangan. Pada penelitian Syarief (1991) dalam Renate (2009), diketahui bahwa faktor utama yang mempengaruhi pertumbuhan mikroorganisme antara lain adalah aktivitas air bahan pangan, semakin tinggi kadar air pada bahan pangan maka semakin tinggi pula aktivitas air yang dimiliki oleh bahan pangan.

Analisa perhitungan angka lempeng total mikroba dilakukan untuk mengetahui sejauh mana masing-masing pengemas dapat menghambat pertumbuhan mikrroorganisme. Tabel 2 menunjukkan bahwa total mikroorganisme pada pengemas berbahan LDPE memiliki total mikroorganisme paling tinggi diantara jenis pengemas lainnya. Sedangkan pada plastik pengemas lainnya, nilai angka lempeng total mikroba diketahui cukup rendah. Kondisi ini disebabkan oleh adanya perbedaan permeabilitas udara yang cukup tinggi, Sifat inilah yang menyebabkan kadar air didalam kemasan LDPE meningkat.

Tabel 2. Perhitungan angka lempeng total mikroba manisan kering terong

\begin{tabular}{|c|c|c|c|c|c|}
\hline \multirow[t]{2}{*}{ Sampel } & \multicolumn{5}{|c|}{ Pengenceran } \\
\hline & $10^{-1}$ & $10^{-2}$ & $10^{-3}$ & $10^{-4}$ & $10^{-5}$ \\
\hline Tanpa Kemasan & 3 & 2 & 2 & 2 & 3 \\
\hline Plastik mika (PE) & 1 & 0 & 0 & 0 & 0 \\
\hline Plastik PET & 3 & 1 & 0 & 0 & 1 \\
\hline Plastik LDPE & 2 & 2 & 1 & 1 & 0 \\
\hline Plastik alu+LDPE & 1 & 0 & 0 & 1 & 0 \\
\hline
\end{tabular}

Pengemas tipe PE memiliki permeabilitas udara cukup tinggi namun permeabilitas uap air dan air yang rendah, keadaan inilah yang menyebabkan jumlah mikroorganisme yang tumbuh pada manisan tidak sebanyak pada pengemas lain yang berbahan dasar PET dan LDPE. Rendahnya kadar air yang dimiliki manisan kering terung pada kemasan berbahan PE menyebabkan mikroorganisme tidak dapat tumbuh.

Data penelitian pada produk manisan kering terung hijau tanpa kemasan menunjukkan bahwa jumlah mikroorganisme lebih banyak daripada manisan kering terung hijau yang mengalami pengemasan. Hal ini jelas menunjukkan bahwa proses pengemasan mampu 
melindungi produk dari kontaminasi mikroorganisme dan memperpanjang umur simpan dari produk.

\section{KESIMPULAN}

Dari hasil penelitian dapat disimpukan bahwasanya

1. Jenis pengemas terbaik yang dapat digunakan untuk mengemas makanan dengan kadar gula tinggi dan kadar air rendah adalah jenis plastik PE, dengan nilai kadar air paling rendah daripada semua pengemas yang digunakan yaitu sebesar 33,88\%.

2. Hasil analisa Angka lempeng total mikroba (ALT) menunjukkan bahwa kemasan dengan jenis plastik LDPE memiliki jumlah mikroba lebih banyak dibandingkan kemasan yang lain.

3. Permeabilitas kemasan merupakan faktor utama dalam pemilihan kemasan, hal ini diperlukan untuk menjaga kadar air dan gas didalam kemasan untuk mempertahankan produk didalamnya.

\section{DAFTAR PUSTAKA}

Atma Y. 2016. Angka Lempeng Total (ALT), Angka Paling Mungkin (APM) dan Total Kapang Khamir Sebagai Metode Analisis Sederhana Untuk Menentukan Standar Mikrobiologi Pangan Olahan Posdaya. Jurnal Teknologi 8(2):77-82.

Badan Standarisasi Nasional. (1998). Manisan Pala-SNI 01-4443-1998. Jakarta.

Johansyah A, Prihastanti E, Kusdiyantini. 2014. Pengaruh Plastik Pengemas Low Density Polyethylene (LDPE), High Density Polyethylene (HDPE) dan Polipropilen (PP) Terhadap Penundaan Kematangan Buah Tomat (Lycopersican esculentum. Mill). Buletin Anatomi dan Fisiologis. Vol 22(1):46-57.

Mujiarto I. 2005. Sifat dan Karakteristik Matertal Plastik dan Bahan Aditif. Traksi 3(2):6573.

Nofriati D. 2013. Kajian Pengawetan Manisan Kering Buah Nanas (Ananas comosus L.Merr) Selama Masa Penyimpanan. Jurnal Agroindustri 3(2): 77-82.

Pratami N. 2012. Proses Produksi Manisan Basah Pare. Tugas Akhir. Program Studi Diploma III. Teknologi Hasil Pertanian. Fakultas Pertanian. Universitas Sebelah Maret. Surakarta. 
Putri MKN, Gunawan I, Suarsa I. 2015. Aktivitas Antioksidan Antosianin Dalam Ekstrak Etanol Kulit Buah Naga Super Merah (Hylocereus costaricensis) Dan Analisis Kadar Totalnya. Jurnal Kimia 9(2):243-251.

Renate D. 2009. Pengemasan Puree Cabe Merah. Jurnal Teknologi Industri dan Hasil Pertanian 14(1):80-89.

Santoso, H.B. (2016). Halaman Organik Minimalis - Sehat Dengan Menyulap Tanaman Sempit Rumah Jadi Tanaman Sayuran Organik. Lily Publisher. Yogyakarta.

Syarief.R. dan A. Syukri. (2016). Pengemasan Pangan. Universitas Terbuka. Tangerang.

Windyasari C, Wignyanto, Ikaputri W. 2012. Pengembangan Belimbing Wuluh (Averrhoa bilimbi) Sebagai Manisan Kering Dengan Kajian Konsentrasi Perendaman Air Kapur $(\mathrm{Ca}(\mathrm{OH}) 2)$ dan Lama Waktu Pengeringan. Jurnal Industri 1(3):195-203.

Wulandari A, Waluyo S, Noviya D. 2013. Prediksi Umur Simpan Kerupuk Kemplang Dalam Kemasan Plastik Polipropilen Beberapa Ketebalan. Jurnal Teknik Pertanian Lampung 2(2):105-114. 